\title{
COMPARISON OF CRYPTO-ASSETS MARKET RISK PROXIES*
}

\author{
Aleksander Mercik \\ Wrocław University of Economics and Business \\ e-mail: aleksander.mercik@ue.wroc.pl
}

ORCID: 0000-0003-1076-6619

\section{Daniel Cupriak}

Wrocław University of Economics and Business

e-mail: 165524@student.ue.wroc.pl

ORCID: 0000-0001-8097-5622

(C) 2021 Aleksander Mercik, Daniel Cupriak

This work is licensed under the Creative Commons Attribution-ShareAlike 4.0 International License. To view a copy of this license, visit http://creativecommons.org/licenses/by-sa/4.0/

Quote as: Mercik, A. i Cupriak, D. (2021). Comparison of crypto-assets market risk proxies. Financial Sciences, 26(1).

DOI: 10.15611/fins.2021.1.04

JEL Classification: G11, G10, G14, F31, G12

\begin{abstract}
In early 2021, the cryptoasset market capitalization exceeded $\$ 1.5$ trillion, and there were more than 300 exchanges in the world where over 8,000 tokens could be traded. As part of research related to mature segments of the financial market (e.g. the stock market in the United States), scientists and practitioners have been trying to identify key risk factors for several decades, thanks to which it is possible to explain the equity risk premium for an investment in a given asset class. In recent years, there have been an increasing number of researchers trying to identify these factors for cryptoassets. The aim of this article was to analyse popular cryptoasset indices in order to identify those that can be used as a proxy of the market portfolio in order to estimate this risk factor premium. The research results indicate that the market risk factor is an important element of the market under study, and the indices that best reflect it are an index consisting of all cryptoassets weighted by capitalization and Coin100 which contains only the 100 largest cryptoassets.
\end{abstract}

Keywords: cryptoassets, digital tokens, blockchain, cryptocurrency, systematic risk, CAPM.

* The research was carried out under the Scientific and Research Excellence Program - INTEREKON "Regional Excellence Initiative" of the Ministry of Science and Higher Education. The project title is: "Applications of blockchain technology: the financial analysis of real applications based on functional and sector criteria." 


\section{Introduction}

Cryptoassets are digital representations of values or rights that can be transferred and stored electronically using distributed ledger technology or similar technology (Proposal for a Regulation..., 2019). In recent years, cryptocurrency and blockchain technology have attracted millions of investors. In early 2021, the cryptocurrency market capitalization exceeded \$1.5 trillion, and there were over 300 exchanges in the world where over 8,000 digital tokens could be traded. ${ }^{1}$ According to some researchers and practitioners, blockchain technology and cryptoassets can improve the lives of millions of people (Iansiti \& Lakhani, 2017). Examples of the challenges which may be faced include a lack of access to basic financial services for 2 billion people worldwide (Larios-Hernández, 2017) and a lack of access to any register of the 5 billion people who own cryptoassets (Soto de, 2017). On the other hand, the cryptoasset market is widely unregulated and as such, opponents of cryptoassets argue that digital tokens often become the subject of speculation or even manipulation (Gandal, Hamrick, Moore, \& Oberman, 2018; Li, Shin, \& Wang, 2018).

Basic information on blockchain technology and its potential can be found in the publications by Dwyer (2015), Underwood (2016) and Larios-Hernández (2017). The discussed technological solutions may have development potential in various spheres of the economy, including organization management, finance and accounting, and sales and marketing (Tapscott \& Tapscott, 2017). Other potential applications are contracting, auditing and verification of products (e.g. food) and so on (Fanning \& Centers, 2016).

Scientific research on the cryptoasset market has been conducted for only a few years, but the number of publications is increasing, as confirmed by statistics from the Web Of Science and Scopus databases. The subject of the first articles was most often the so-called cryptocurrencies (falling under the definition of cryptoassets) with the largest market capitalization, such as Bitcoin, Ethereum, Ripple and so on. At first, less attention was paid to much smaller projects using blockchain technology, which also issued digital tokens with different characteristics and applications.

In research related to mature segments of the financial market (e.g. the stock market in the United States), scientists and practitioners have been trying to identify key risk factors for decades, thanks to which it is possible to explain the so-called equity risk premium for an investment in a given asset class. The possibility of determining this parameter is also an important element in the process of valuating many financial instruments. The capital asset pricing model (CAPM) was the first model independently proposed by Treynor (1962) and Sharpe (1964) based on earlier work by Markowitz (1952) and was used to explain the size of the equity risk premium. In this model, the only factor was the so-called market risk factor.

\footnotetext{
${ }^{1}$ https://coinmarketcap.com/ (as of 18 February 2021).
} 
Numerous studies conducted in the following decades clearly indicate that this model should be supplemented with other factors, such as the size of the company, the relations between the book value and market value, profitability and historical trends. The key research in this area was published by Fama and French (1992). According to them, the one-factor model should be completed with two other factors related to the size of the company (SMB factor) and the book-to-market ratio (HML factor), which is often referred to as the Fama-French three-factor model (Fama and French, 1992). In the following years, many authors proposed models with even more factors. Empirical research has been presented, among others, in the publications of Fama and French (2013; 2015), Nichol and Dowling (2014), Chiah, Chai, Zhong, \& Li (2016), as well as Fabozzi and Wang (2016). As part of the research conducted in Poland, they have been verified by Urbański (2007), Kowerski (2008), Czapkiewicz and Skalna (2010), Waszczuk (2013), Zaremba (2014) and Czapiewski (2016), among others.

After the publication of the first research focusing on Bitcoin price changes, it became clear that it is used more as a speculative asset than as a means of payment (Baur, Hong, \& Lee, 2018; Corbet, Meegan, Larkin, Lucey, \& Yarovaya, 2018), but it can be an attractive diversification tool (Bouri, Molnár, Azzi, Roubaud, \& Hagfors, 2017; Dyhrberg, 2016). In light of other studies, the cryptoasset market provides the opportunity to use numerous active investment strategies due to the emerging inefficiencies. For example, studies show that the use of stop-loss orders reduces the volatility of investments in individual cryptoassets by almost half (Białkowski, 2020). Other studies that focus on the effectiveness of the cryptoasset market include: Urquhart (2016), Gandal et al. (2018), Nadarajah and Chu (2017), Bariviera (2017), Cheah and Fry (2015), and Corbet, Lucey, and Yarovaya (2017).

Referring to the CAPM and its developments, an attempt has been made to identify the key risk factors, thanks to which it is possible to explain the realized rates of return on a wide range of cryptoassets. In their studies, Coelho (2020) as well as Liu and Tsyvinski (2018) have analysed the possibility of using the Fama-French three-factor model. A significant influence of factors related to the momentum and capitalization on the rates of return on cryptoassets has also also been demonstrated (Liu, Tsyvinski, A., \& Wu, 2019). Long, Zaremba, Demir, Szczygielski, and Vasenin (2020) conducted research indicating the occurrence of seasonal phenomena. Excess returns were also examined by Zhang and Li (2020) and Borri and Shakhnov (2018).

The abovementioned works describe empirical studies referring to the concept of the decomposition of the observed rates of return into factors that determine them, including the market beta. Nevertheless, the time series representing the market risk factor is often chosen arbitrarily despite the fact that many cryptoasset market indices have emerged in recent years. For example, Long et al., (2020) and Zhang and Li (2020), in the single and multi-factor models, used a portfolio consisting of all cryptocurrencies weighted by capitalization. In other works, the benchmark was the 
rates of return on investments in Bitcoin (e.g. Borri and Shakhnov, 2018). The aim of this article was to compare popular cryptoasset indices in order to select those that may reflect the market risk factor. For this purpose, eight indices and two cryptocurrencies with the largest capitalization - Bitcoin and Ethereum are compared. This study is a continuation of the research conducted by Mercik and Cupriak (2019).

This article is divided into four chapters. Chapter 2 describes the sources of the data obtained and the research methodology. Chapter 3 discusses the results obtained. Chapter 4 is a summary supplemented with the perspective of the research conducted.

\section{Source material and research methods}

The main source of data in the study was https://coinpaprika.com/, which publishes prices from the most liquid digital token exchanges in the world. The analysed time series covered the period from January 2017 to the end of January 2021 (49 months in total). Such a period was selected mainly because of data availability - before January 2017 the number of digital tokens was too small to perform a broad market study, moreover data for a large number of cryptoassets prominent before 2017 are unavailable now due to delisting from data aggregating platforms.

Data were obtained in the open, high, low, close, volume (OHLCV) format for 4,963 projects. However, for 172 projects no capitalization data were available for any period, so these projects were excluded from further analysis. It should be emphasized that only small projects and those characterized by low liquidity did not have data on capitalization. In those 4,791 projects with data on capitalization, a subgroup of 2,793 projects built with the use of blockchain networks from other projects (e.g. Ethereum) were identified. These kinds of projects are referred to as 'tokens' for the purposes of this article, in contrast to projects using a proprietary network called 'coins', 1998 of which were identified. In the course of the study, 42 projects were identified that contained errors in their time series in the data about the closing price or market capitalization. Due to the inability to determine the appropriate values for these data, these projects were excluded from the analysis.

To conduct the study it was necessary to prepare monthly rates of return on three additional indices that represent the entire cryptoasset market (4,791 projects called the "CoinMarket" in this study), the entire market of tokens issued in the existing networks such as the Ethereum network, which is the most popular platform (the socalled "TokenMarket", 2,793 projects) and 100 cryptoassets with the highest capitalization ("Coin 100"). Moreover, five cryptoasset indices existing on the market were selected for comparison: CRIX (Trimborn \& Härdle, 2018), CCI30 (Rivin \& Scevola, 2018, p. 3), CMC200 (Crypto200 Index by Solactive, n.d.), CCMIX (Crescent Crypto Market Index, n.d.) and Crypto20 (Schwartzkopff, Schwartzkopff, Botha, Finlayson, \& Cronje, 2017). The monthly rates of return on the indices are shown in Figure 1. 

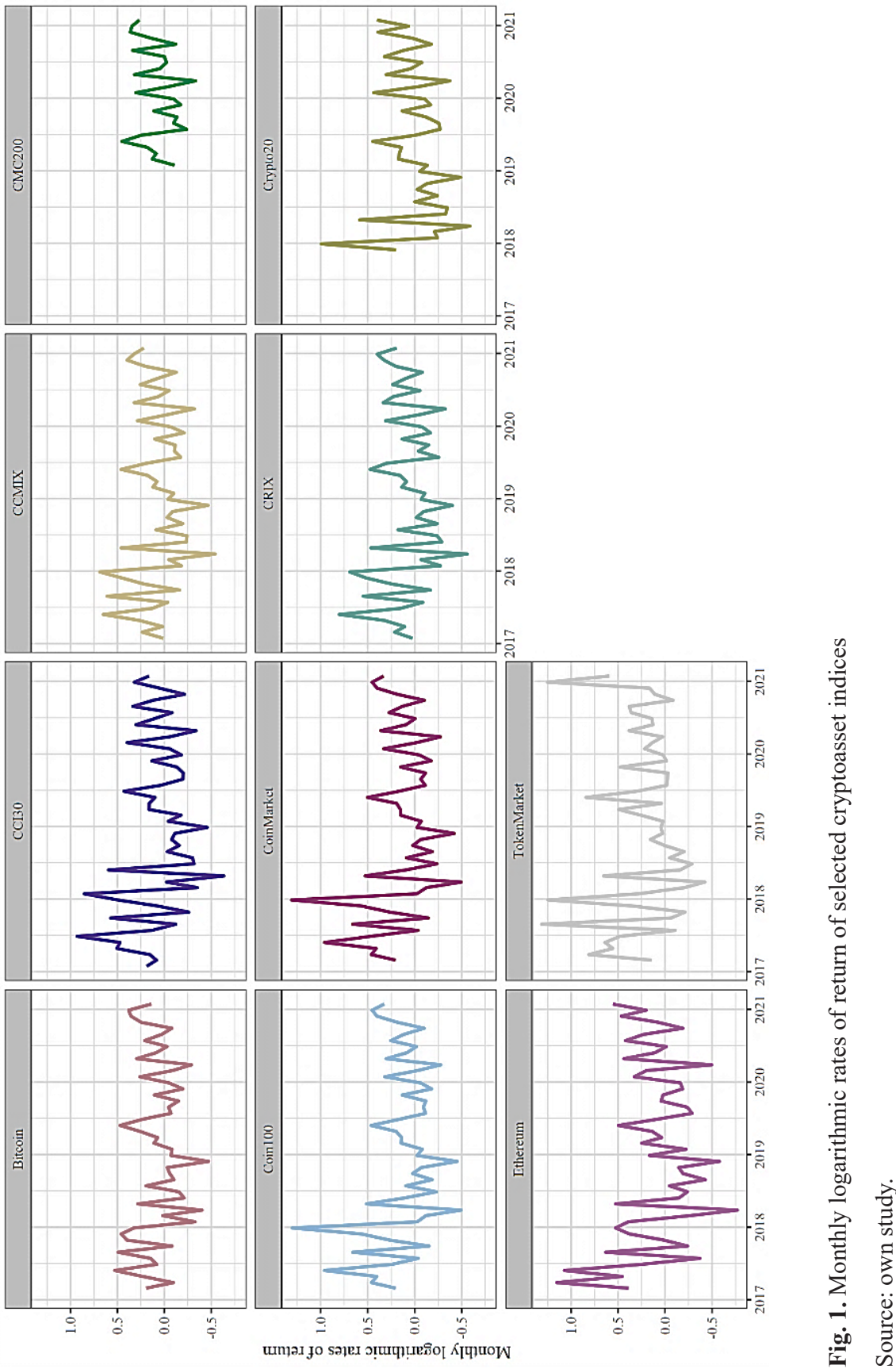
According to the definition, the market portfolio (which is the basis of the CAPM model) is on the efficient frontier, whose ratio of the excess return over the return on risk-free instruments to the risk taken (measured by the standard deviation of the rates of return) is the largest (Jajuga \& Jajuga, 2004). Thus, one of the crucial criteria that a potential market portfolio proxy should meet is a high risk-return efficiency. A graphical interpretation of the market portfolio is shown in Figure 2.

Fig. 2. Market portfolio and the efficient frontier Source: own study.

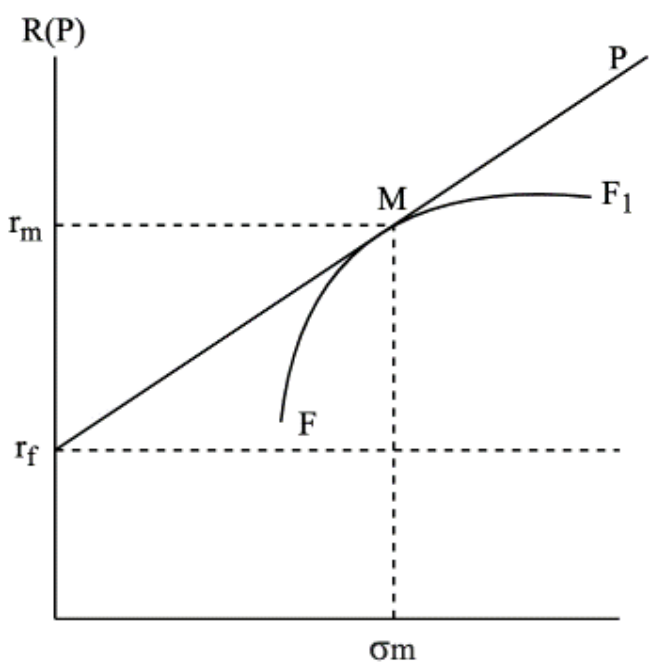

In the figure, the symbol $\mathrm{R}(\mathrm{P})$ represents the rate of return on the portfolio, $\mathrm{r}_{\mathrm{f}}-$ the risk-free rate, $r_{m}$ - the rate of return on the market portfolio, $\sigma_{m}$ - standard deviation of the market portfolio, $\mathrm{M}$ - the point where the market portfolio is located, $\mathrm{P}$ - the capital market line, the curve represents the efficiency curve, and $\mathrm{F}$ and $\mathrm{F}_{1}$ are examples of portfolios on this curve.

The study verified ten instruments that may constitute an appropriate approximation of the rates of return on the market portfolio. These were the rates of return on: Bitcoin, Ethereum, CoinMarket, TokenMarket, Coin100, CRIX (Trimborn \& Härdle, 2018), CCI30 (Rivin \& Scevola, 2018, p. 3), CMC200 (Crypto200 Index by Solactive, n.d.), CCMIX (Crescent Crypto Market Index, n.d.) and Crypto20 (Schwartzkopff et al., 2017). To indicate the index that best suits the role of a market portfolio proxy, two main characteristics had to be tested: risk-return efficiency, as the market portfolio is by definition efficient in this regard, and high correlation with all other assets in the market due to the fact that the market portfolio has to reflect all systemic changes in the market as a whole.

The research procedure was divided into three stages. First, the mean, standard deviation, skewness and kurtosis of monthly logarithmic rates of return were calculated for all the analysed indices. Then the ratio of the average implemented monthly logarithmic rates of return to risk (standard deviation) was calculated and 
the index with the highest value was indicated. Moroever, a number of basic statistical tests were carried out for each index to assess the statistical characteristics of each time-series. These included: the Augmented Dickey-Fuller test, which tests the presence of the unit root in the autoregressive model; the KPSS test, which aims to verify the null hypothesis that an observable time series is stationary; the Ljung-Box test, which checks the autocorrelation of a time series; the Wald-Wolfowitz Runs test, which verifies the randomness of the sample; and the ARCH test, which verifies the effect of the autocorrelation of the squared rates of return. At the second stage, the share of tokens statistically significantly correlated with each index was estimated for each index. This approach is aimed at identifying tokens whose rates of return can be explained using each of the indices. Then, the obtained results were visualized by presenting the distribution of correlation coefficients in a strip chart. Finally, at the third stage of the study, the correlation matrix was estimated for all ten indices in order to identify those that differed insignificantly from each other. At the end of the research procedure, an index was indicated that could satisfactorily reflect the market risk factor and thus explain the price changes of many other instruments on the cryptoasset market.

\section{Results of empirical research}

Table 1 shows the basic descriptive statistics for the ten analysed indices. Additionally, the Shapiro-Wilk test was performed for a number of rates of return. This recognized test checks the normality of the distribution of a random variable (Shapiro \& Wilk, 1965), which was chosen because of its high test power (Razali \& Wah, 2011). The TokenMarket index has the highest realized risk to profit ratio. Each of the analysed indices is characterized by different values of the rates of return over time (the first quartiles are negative in each case, and the third quartiles are three times higher than the

Table 1. Descriptive statistics of selected indices

\begin{tabular}{|l|c|c|c|c|c|c|c|c|c|}
\hline \multicolumn{1}{|c|}{ Index } & $\begin{array}{c}\text { Sample } \\
\text { size }\end{array}$ & $\begin{array}{c}\text { Mean } \\
{[\%]}\end{array}$ & $\begin{array}{c}\text { First } \\
\text { quartile } \\
{[\%]}\end{array}$ & $\begin{array}{c}\text { Third } \\
\text { quartile } \\
{[\%]}\end{array}$ & $\begin{array}{c}\text { Standard } \\
\text { deviation } \\
{[\%]}\end{array}$ & $\begin{array}{c}\text { Skewness } \\
{[\%]}\end{array}$ & $\begin{array}{c}\text { Kurtosis } \\
{[\%]}\end{array}$ & $\begin{array}{c}\text { Mean- } \\
\text { to-risk } \\
{[\%]}\end{array}$ & $\begin{array}{c}\text { Shapiro- } \\
\text { Wilk test } \\
{[\%]}\end{array}$ \\
\hline Bitcoin & 48 & 7.4 & -8.1 & 25.0 & 23.8 & -6.5 & 245.2 & 30.86 & 98.17 \\
\hline CCI30 & 49 & 6.9 & -15.8 & 18.9 & 32.3 & 52.3 & 323.2 & 21.20 & 97.45 \\
\hline CCMIX & 49 & 7.2 & -10.7 & 23.5 & 27.1 & 24.3 & 287.3 & 26.58 & 98.35 \\
\hline CMC200 & 25 & 7.8 & -9.8 & 26.4 & 21.4 & -2.1 & 193.7 & 36.42 & 96.50 \\
\hline Coin100 & 48 & 13.8 & -8.4 & 30.7 & 33.1 & 104.8 & 514.9 & $\mathbf{4 1 . 5 8}$ & 93.73 \\
\hline CoinMarket & 48 & 14.9 & -6.6 & 33.8 & 33.5 & 98.7 & 485.9 & $\mathbf{4 4 . 5 5}$ & 94.33 \\
\hline CRIX & 49 & 8.2 & -9.6 & 24.1 & 28.7 & 25.1 & 282.2 & 28.72 & 98.87 \\
\hline Crypto20 & 39 & 1.4 & -19.3 & 16.7 & 31.4 & 74.3 & 395.4 & 4.36 & 96.58 \\
\hline Ethereum & 48 & 10.0 & -19.0 & 38.9 & 39.2 & 35.0 & 328.4 & 25.55 & 97.80 \\
\hline TokenMarket & 48 & 23.3 & -1.9 & 40.6 & 39.2 & 109.4 & 396.0 & $\mathbf{5 9 . 3 3}$ & 91.01 \\
\hline
\end{tabular}

Source: own study. 
average). Moreover, the rates of return on the indices are characterized by high volatility, and the lowest standard deviation value is as high as $27.1 \%$. With the exception of Bitcoin and the CMC200, the rates of return on the indices are leptokurtic and right-skewed. Based on the Shapiro-Wilk test, the hypothesis about the normality of the distribution of the monthly logarithmic rates of return for the analysed indices cannot be rejected.

Table 2 shows the results of a series of basic tests: the Augmented Dickey-Fuller test, the KPSS test, the Ljung-Box test, the Wald-Wolfowitz Runs test and the ARCH test, while Table 3 contains the p-values for these tests. The results obtained indicate that the time series which are the basis for further research can be considered stationary. In the case of two indices (Crypto20 and Ethereum), there is a unit root in a series of rates of return. The ARCH effect was observed for the Coin100 index. No autocorrelation of the rates of return was observed in the analysed indices.

Table 2. Results of statistical tests for selected indices

\begin{tabular}{|l|l|l|l|l|l|}
\hline \multicolumn{1}{|c|}{ Index } & \multicolumn{1}{c|}{ ADF $[\mathrm{H}]$} & KPSS $[\mathrm{H}]$ & \multicolumn{1}{c|}{ Ljung-Box $[\mathrm{H}]$} & \multicolumn{1}{c|}{ Runs $[\mathrm{H}]$} & \multicolumn{1}{c|}{ ARCH test $[\mathrm{H}]$} \\
\hline Bitcoin & Stationary & Stationary & No autocorrelation & Random sample & No ARCH effect \\
\hline CCI30 & Stationary & Stationary & No autocorrelation & Random sample & No ARCH effect \\
\hline CCMIX & Stationary & Stationary & No autocorrelation & Random sample & No ARCH effect \\
\hline CMC200 & Stationary & Stationary & No autocorrelation & Random sample & No ARCH effect \\
\hline Coin100 & Stationary & Stationary & No autocorrelation & Random sample & ARCH effect present \\
\hline CoinMarket & Stationary & Stationary & No autocorrelation & Random sample & No ARCH effect \\
\hline CRIX & Stationary & Stationary & No autocorrelation & Random sample & No ARCH effect \\
\hline Crypto20 & Nonstationary & Stationary & No autocorrelation & Random sample & No ARCH effect \\
\hline Ethereum & Nonstationary & Stationary & No autocorrelation & Random sample & No ARCH effect \\
\hline TokenMarket & Stationary & Stationary & No autocorrelation & Random sample & No ARCH effect \\
\hline
\end{tabular}

Source: own study.

Table 3. P-values for statistical tests for selected indices

\begin{tabular}{|l|c|c|c|c|c|}
\hline \multicolumn{1}{|c|}{ Index } & $\begin{array}{c}\text { ADF } \\
\text { p-value }\end{array}$ & KPSS p-value & $\begin{array}{c}\text { Ljung-Box } \\
\text { p-value }\end{array}$ & Runs p-value & $\begin{array}{c}\text { ARCH test } \\
\text { p-value }\end{array}$ \\
\hline Bitcoin & $39 \%$ & $10 \%$ & $31 \%$ & $24 \%$ & $81 \%$ \\
\hline CCI30 & $36 \%$ & $10 \%$ & $66 \%$ & $55 \%$ & $20 \%$ \\
\hline CCMIX & $52 \%$ & $10 \%$ & $64 \%$ & $55 \%$ & $57 \%$ \\
\hline CMC200 & $66 \%$ & $10 \%$ & $59 \%$ & $57 \%$ & $37 \%$ \\
\hline Coin100 & $34 \%$ & $10 \%$ & $14 \%$ & $10 \%$ & $4 \%$ \\
\hline CoinMarket & $36 \%$ & $10 \%$ & $12 \%$ & $8 \%$ & $7 \%$ \\
\hline CRIX & $40 \%$ & $10 \%$ & $62 \%$ & $53 \%$ & $37 \%$ \\
\hline Crypto20 & $5 \%$ & $10 \%$ & $84 \%$ & $93 \%$ & $17 \%$ \\
\hline Ethereum & $3 \%$ & $10 \%$ & $25 \%$ & $16 \%$ & $7 \%$ \\
\hline TokenMarket & $54 \%$ & $10 \%$ & $58 \%$ & $49 \%$ & $99 \%$ \\
\hline
\end{tabular}

Source: own study. 
Table 4 shows the share of projects (excluding Bitcoin, Ethereum and Crypto20 projects due to their presence in the group of analysed indices) statistically significantly correlated with the selected indices. The obtained results indicate that the Crypto20 index, whose token can be compared to an index fund unit of the 20 cryptocurrencies with the highest capitalization (excluding the so-called stablecoins), is characterized by the highest share of significantly correlated projects. Moreover, the Ethereum and CoinMarket indices are characterized by a high share of significantly correlated projects. It should be noted that the CMC200 and Crypto20 indices have smaller research samples than the other indices, which may explain the differences in the share of significantly correlated projects.

Table 4. Share of statistically significant correlation coefficients between projects and selected indices

\begin{tabular}{|l|c|c|}
\hline \multicolumn{1}{|c|}{ Index } & $\begin{array}{c}\text { Number of significantly } \\
\text { correlated projects }\end{array}$ & $\begin{array}{c}\text { Share of significantly correlated } \\
\text { projects }\end{array}$ \\
\hline Bitcoin & 1,281 & $38.33 \%$ \\
\hline CCI30 & 210 & $6.28 \%$ \\
\hline CCMIX & 1,489 & $44.55 \%$ \\
\hline CMC200 & 774 & $23.16 \%$ \\
\hline Coin100 & 1,491 & $44.61 \%$ \\
\hline CoinMarket & $\mathbf{1 , 5 1 9}$ & $\mathbf{4 5 . 4 5 \%}$ \\
\hline CRIX & 1,438 & $43.03 \%$ \\
\hline Crypto20 & $\mathbf{1 , 5 6 7}$ & $\mathbf{4 6 . 8 9 \%}$ \\
\hline Ethereum & $\mathbf{1 , 5 5 1}$ & $\mathbf{4 6 . 4 1 \%}$ \\
\hline TokenMarket & 1,211 & $36.24 \%$ \\
\hline
\end{tabular}

Source: own study.

Figure 3 shows a strip chart of the correlation coefficients for the studied indices. Each point on the chart shows the correlation coefficient between a given index and a single project from the database (excluding Bitcoin, Ethereum and Crypto20 projects due to their presence in the group of analyzed indices). The large colourcoded dots indicate the mean correlation coefficient, and the coloured lines indicate a range of 1.5 standard deviations from the mean. With the exception of the CCI30 index, which on average is least correlated with projects, for each index, all the values within 1.5 standard deviations from the mean are greater than 0.25 and lower than 0.675 .

An interesting phenomenon is the negative correlation in some projects, which are often called 'stablecoins'. By definition, these tokens should not be subject to price fluctuations or their price volatility should be minimal. In some cases, their value corresponds to the dollar value in a 1:1 ratio. Examples include the Tether USDT (https://tether.to) and TrueUSD projects (https://www.trusttoken.com/). 


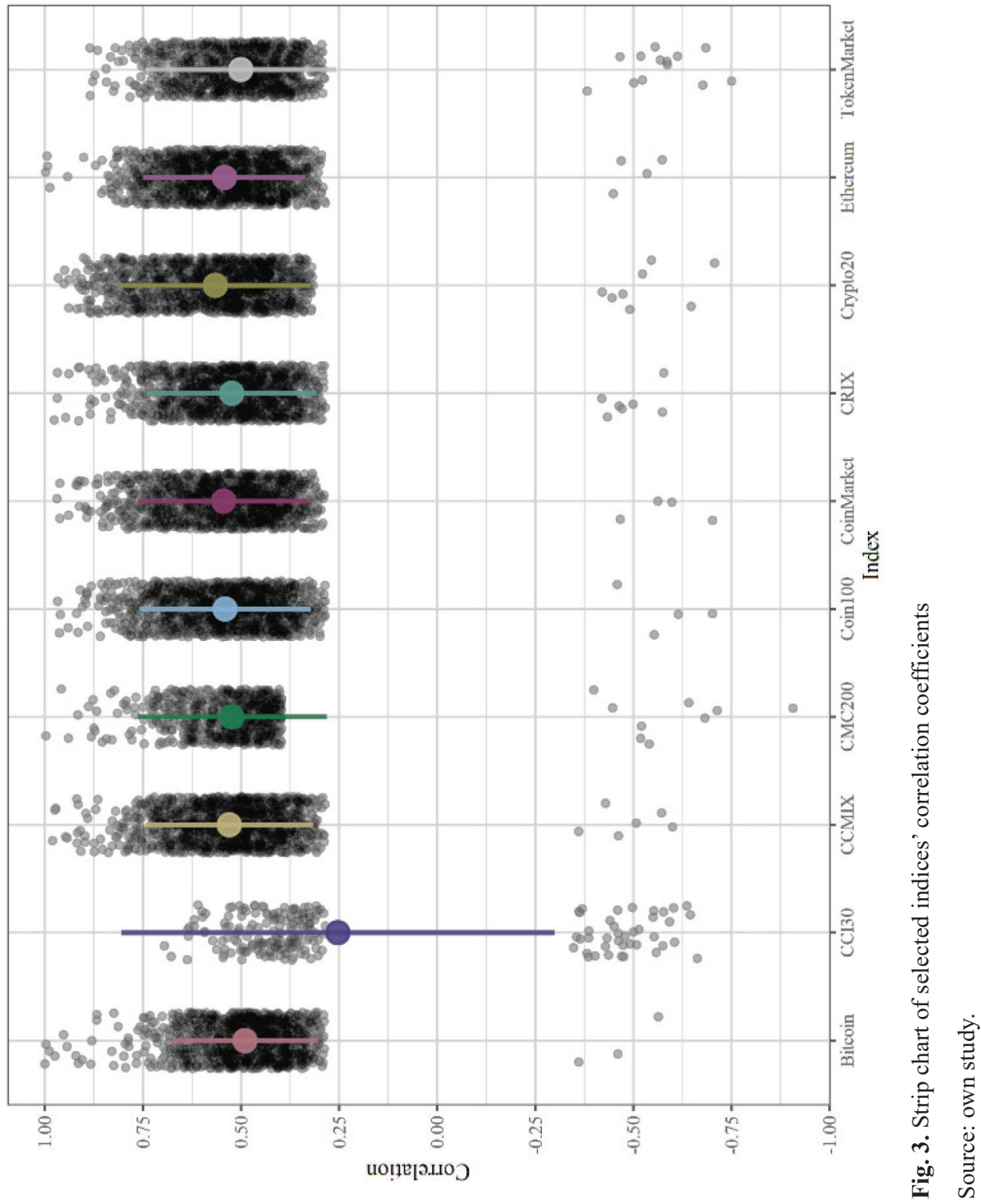


Table 5 shows the statistics describing the distribution of correlation coefficients for the studied indices. Except for the CCI30 index, the interquartile distribution of the correlation coefficients for each index ranges from 0.406 to 0.559 . The medians of the correlation coefficients for each of the analysed indices, except for CCI30, are over 0.48 , which proves a relatively high degree of correlation between the studied indices and individual cryptoassets. The Crypto20, Ethereum, CoinMarket and Coin100 indices have the highest correlation coefficient medians.

Table 5. Descriptive statistics of statistically significant correlation coefficients between projects and selected indices

\begin{tabular}{|l|c|c|c|c|c|}
\hline \multicolumn{1}{|c|}{ Index } & $\begin{array}{c}5 \% \\
\text { Percentile }\end{array}$ & $\begin{array}{c}\text { First } \\
\text { quartile }\end{array}$ & Median & $\begin{array}{c}\text { Third } \\
\text { quartile }\end{array}$ & $\begin{array}{c}95 \% \\
\text { Percentile }\end{array}$ \\
\hline Bitcoin & 0.333 & 0.406 & 0.480 & 0.559 & 0.680 \\
\hline CCI30 & -0.551 & 0.310 & 0.378 & 0.461 & 0.595 \\
\hline CCMIX & 0.345 & 0.439 & 0.521 & 0.620 & 0.754 \\
\hline CMC200 & 0.406 & 0.450 & 0.511 & 0.602 & 0.721 \\
\hline Coin100 & $\mathbf{0 . 3 4 8}$ & $\mathbf{0 . 4 4 1}$ & $\mathbf{0 . 5 3 3}$ & $\mathbf{0 . 6 3 7}$ & $\mathbf{0 . 7 7 6}$ \\
\hline CoinMarket & $\mathbf{0 . 3 4 8}$ & $\mathbf{0 . 4 4 4}$ & $\mathbf{0 . 5 3 5}$ & $\mathbf{0 . 6 3 9}$ & $\mathbf{0 . 7 8 2}$ \\
\hline CRIX & 0.341 & 0.431 & 0.520 & 0.613 & 0.743 \\
\hline Crypto20 & $\mathbf{0 . 3 6 0}$ & $\mathbf{0 . 4 5 3}$ & $\mathbf{0 . 5 5 3}$ & $\mathbf{0 . 6 7 2}$ & $\mathbf{0 . 8 2 5}$ \\
\hline Ethereum & $\mathbf{0 . 3 4 6}$ & $\mathbf{0 . 4 4 4}$ & $\mathbf{0 . 5 3 7}$ & $\mathbf{0 . 6 3 7}$ & $\mathbf{0 . 7 6 2}$ \\
\hline TokenMarket & 0.335 & 0.418 & 0.499 & 0.592 & 0.715 \\
\hline
\end{tabular}

Source: own study.

The table in Appendix 1 shows the correlation matrix for ten tested time series. Except for the CCI30 index, all indices are correlated in a statistically significant manner. The highest correlation was noted between the CoinMarket and Coin100 indices, suggesting that the creation of the index based on only the 100 largest projects gives results similar to the analysis of all instruments.

The analysis is supplemented by the figure in Appendix 2, which contains a diagram showing the correlations between the studied rates of return. As can be seen, the CCI30 is characterized by the lowest values of the correlation coefficient with other indices. The diagram was also supplemented with regression lines, for illustrative reasons only (hence a separate table with parameters was not included). The upper half of the diagram lists the correlation coefficients between the indices and statistical significance markers (three stars means significance at $1 \%$, two at $5 \%$, and no stars means the coefficient is statistically non-significant). Histograms of the monthly index returns are plotted on the diagonal of the diagram. 


\section{Conclusion}

The aim of this article was to compare Bitcoin, Ethereum and popular cryptoasset indices in order to select the best reflection of the market risk factor. As a result of the study, it can be concluded that Coin100, CoinMarket and TokenMarket are indices with the best risk-to-return ratio. In this respect, by far the worst instruments are Ethereum, Crypto20, CCI30 and CRIX, which means that only portfolios containing a large amount of cryptoassets ensure the adequate elimination of risk specific to individual assets.

The instruments that are significantly correlated with a substantial part of the individual tokens are: CCMIX, Coin100, CoinMarket, Crypto20 and Ethereum - from $44.55 \%$ to $46.89 \%$ of projects are statistically significantly correlated with these indices. The least attractive instruments in this respect include CCI30 (6.28 \%) CMC200 (23.16 \%), TokenMarket (36.24\%) and Bitcoin (38.33\%). In all cases, except for CCI30, the studied indices are significantly and strongly correlated with each other; for CoinMarket and Coin100, the correlation coefficient is 0.995 .

To summarise, CoinMarket and Coin100 are the indices that best reflect the market risk factor due to their satisfactory performance in regard to risk-return efficiency and correlation to individual assets in the market. It is worth noting that in many practical situations it is much easier to build an index based on the 100 tokens with the highest capitalization than to attempt to aggregate thousands of tokens listed on over 300 exchanges. For this reason, the optimal solution is to choose an index based on 100 tokens. These findings can now be used in future studies of market models for the cryptoasset sphere as well as developing asset pricing methods.

Systematic risk is an important element of the analyzed market. It seems that many investors in the market under study treat digital tokens as a homogeneous asset class. Although the purpose of tokens issued as part of the development of various projects is different, the token price changes are quite similar. In general, it can be said that using overall trends, one can explain a significant number of the price changes of individual projects. 


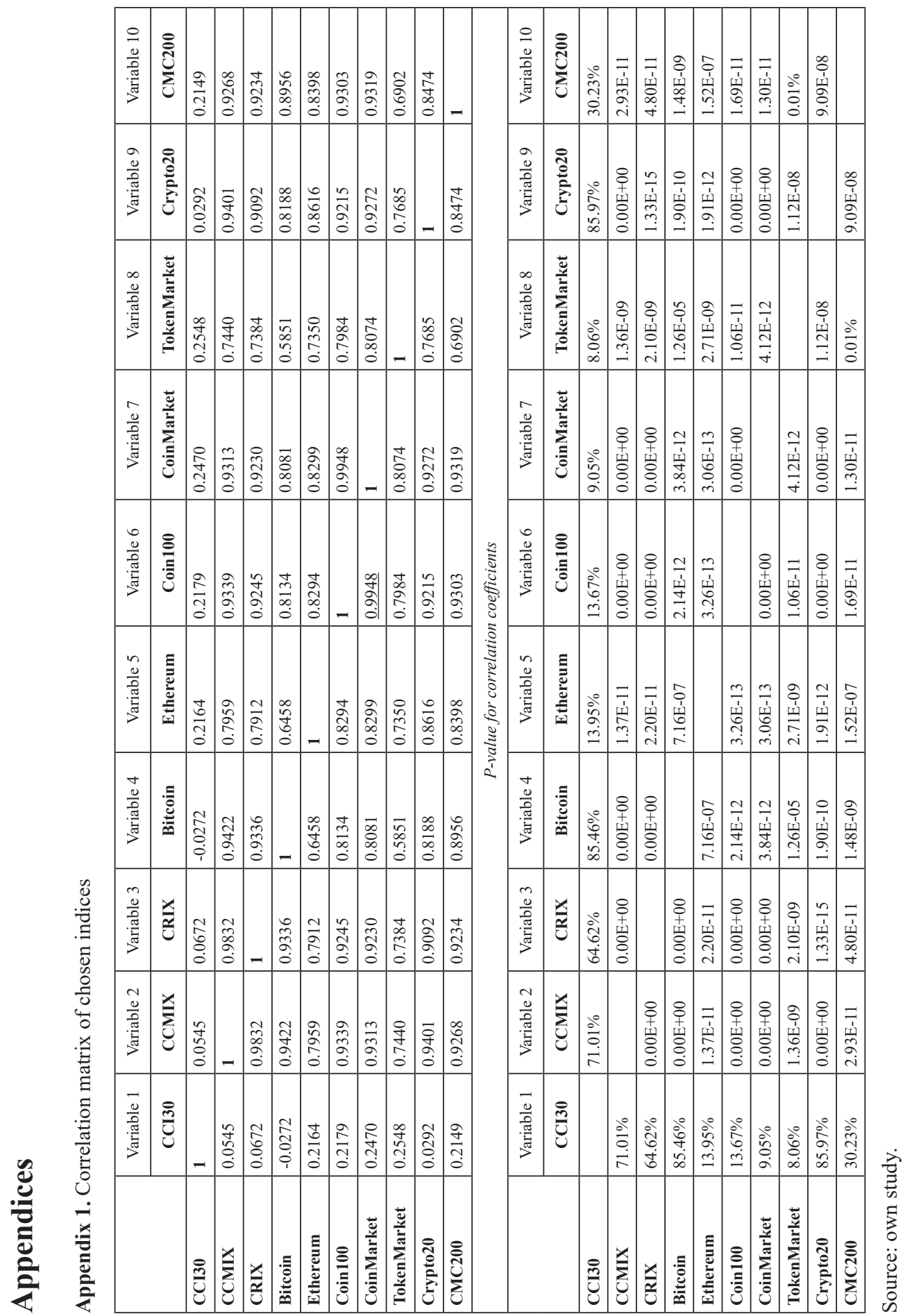



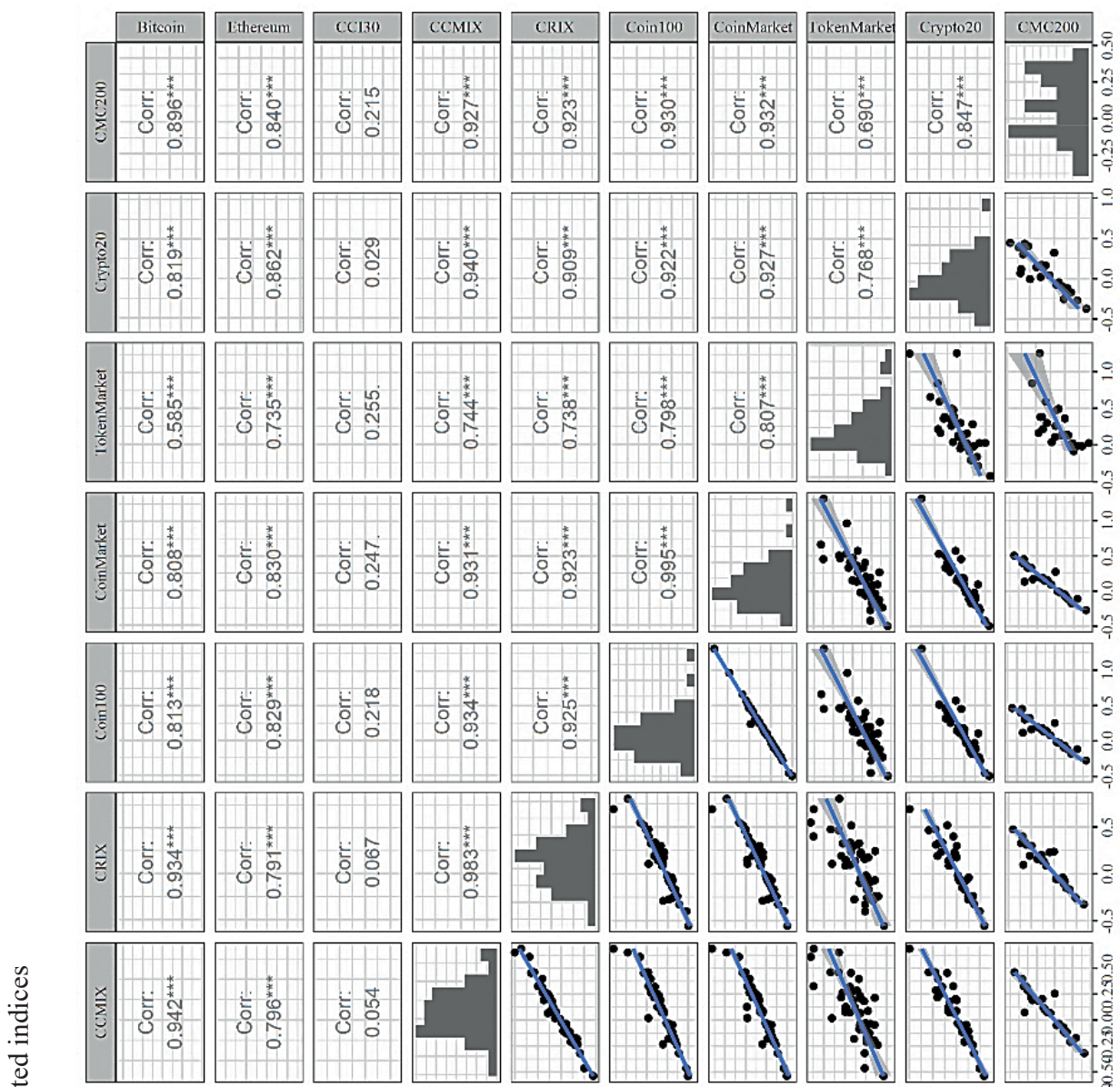

$\frac{d}{0}$

4
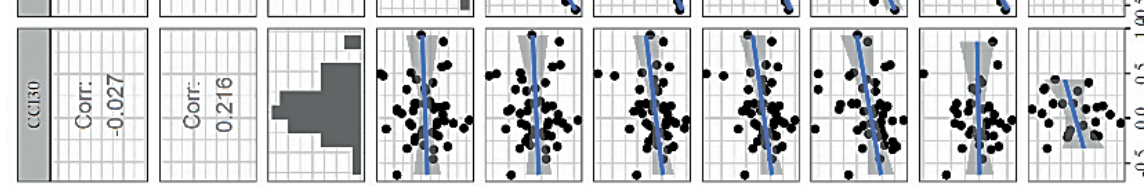

可

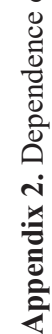
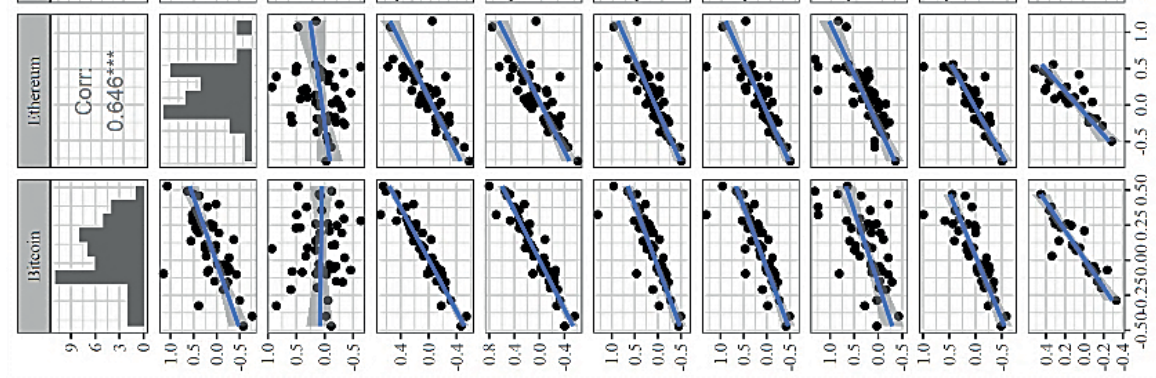

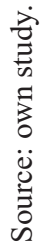




\section{References}

Bariviera, A. F. (2017). The inefficiency of Bitcoin revisited: A dynamic approach. Econ. Lett., (161), 1-4. doi.org/10.1016/j.econlet.2017.09.013

Baur, D. G., Hong, K., \& Lee, A. D. (2018). Bitcoin: Medium of exchange or speculative assets? J. Int. Financ. Mark. Inst. Money, (54), 177-189. doi.org/10.1016/j.intfin.2017.12.004

Białkowski, J. (2020). Cryptocurrencies in institutional investors' portfolios: Evidence from industry stop-loss rules. Econ. Lett., (191), 108834. doi.org/10.1016/j.econlet.2019.108834

Borri, N., \& Shakhnov, K. (2018). The cross-section of cryptocurrency returns. SSRN Electron. J. doi. org/10.2139/ssrn.3241485

Bouri, E., Molnár, P., Azzi, G., Roubaud, D., \& Hagfors, L. I. (2017). On the hedge and safe haven properties of Bitcoin: Is it really more than a diversifier? Finance Res. Lett., (20), 192-198. doi. org/10.1016/j.frl.2016.09.025

Cheah, E.-T., Fry, J., 2015. Speculative bubbles in Bitcoin markets? An empirical investigation into the fundamental value of bitcoin. Econ. Lett., (130), 32-36. doi.org/10.1016/j.econlet.2015.02.029

Chiah, M., Chai, D., Zhong, A., \& Li, S. (2016). A better model? An empirical investigation of the Fama-French five-factor model in Australia: Empirical Tests on the Five-factor Model. International Review of Finance, 16(4), 595-638. https://doi.org/10.1111/irfi.12099

Coelho, D. M. C. (2020). Application of the Fama French three-factor model to the cryptocurrency and token markets. Lisbon: Universidade Católica Portuguesa.

Corbet, S., Lucey, B., \& Yarovaya, L. (2017). Datestamping the Bitcoin and Ethereum bubbles. Finance Res. Lett., (26), 81-88. doi.org/10.1016/j.frl.2017.12.006

Corbet, S., Meegan, A., Larkin, C., Lucey, B., \& Yarovaya, L. (2018). Exploring the dynamic relationships between cryptocurrencies and other financial assets. Econ. Lett., (165), 28-34. doi. org/10.1016/j.econlet.2018.01.004

Crescent Crypto Market Index. (n.d.). Crescent Crypto. Retrieved 18 February 2021 from https://www. crescentcrypto.com/cryptocurrency-market-index/

Crypto200 Index by Solactive. (n.d.). CoinMarketCap. Retrieved 18 February 2021 from https://coinmarketcap.com/indices/

Czapiewski, L. (2016). Performance of the Fama-French five factor model - the case of the Polish capital market. Zesz. Nauk. Uniw. Szczec. Finanse Rynki Finans. Ubezpieczenia, (4), 71-83. doi.org/10.18276/frfu.2016.4.82/2-05

Czapkiewicz, A., \& Skalna, I. (2010). The CAPM and the Fama-French models in the Warsaw Stock Exchange. Przegląd Stat., (57), 128-141.

Dickey, D. A., \& Fuller, W. A. (1979). Distribution of the estimators of autoregressive time series with a unit root. J. Am. Stat. Assoc., (74), 427-431.

Dwyer, G. P. (2015). The economics of Bitcoin and similar private digital currencies. J. Financ. Stab., (17), 81-91. doi.org/10.1016/j.jfs.2014.11.006

Dyhrberg, A. H. (2016). Hedging capabilities of bitcoin. Is it the virtual gold? Finance Res. Lett., (16), 139-144. doi.org/10.1016/j.frl.2015.10.025

Fabozzi, F. J., \& Wang, J. (2016). What difference do new factor models make in portfolio allocation? SSRN Electron. J. doi.org/10.2139/ssrn.2752822

Fama, E., \& French, K. (1992). The cross-section of expected stock returns. J. Finance, (47), 427-465.

Fama, E. F., \& French, K. R. (2013). A Four-Factor model for the size, value, and profitability patterns in stock returns. SSRN Electron. J.. doi.org/10.2139/ssrn.2287202

Fama, E. F., \& French, K. R. (2015). International tests of a five-factor asset pricing model. SSRN Electron. J. doi.org/10.2139/ssrn.2622782

Fanning, K., \& Centers, D. P. (2016). Blockchain and its coming impact on financial services. J. Corp. Account. Finance, (27), 53-57. doi.org/10.1002/jcaf.22179 
Gandal, N., Hamrick, J., Moore, T., \& Oberman, T. (2018). Price manipulation in the Bitcoin ecosystem. J. Monet. Econ., (95), 86-96. doi.org/10.1016/j.jmoneco.2017.12.004

Iansiti, M., \& Lakhani, K. (2017). The truth about blockchain. Harv. Bus. Rev, (95-1), 118-127.

Jajuga, K., \& Jajuga, T. (2004). Inwestycje, Instrumenty finansowe, aktywa niefinansowe, ryzyko finansowe, inżynieria finansowa. Warszawa: Wydawnictwo Naukowe PWN.

Kowerski, M. (2008). Trójczynnikowy model Famy i Frencha dla Giełdy Papierów Wartościowych w Warszawie. Przeglad Stat., (55), 131-148.

Larios-Hernández, G. J. (2017). Blockchain entrepreneurship opportunity in the practices of the unbanked. Bus. Horiz., (60), 865-874. doi.org/10.1016/j.bushor.2017.07.012

Li, T., Shin, D., \& Wang, B. (2018). Cryptocurrency pump-and-dump schemes. SSRN Electron. J. doi. org/10.2139/ssrn.3267041

Liu, Y., \& Tsyvinski, A. (2018). Risks and returns of cryptocurrency (National Bureau of Economic Research, Working Paper Series 24877). doi.org/10.3386/w24877

Liu, Y., Tsyvinski, A., \& Wu, X. (2019). Common risk factors in cryptocurrency (National Bureau of Economic Research, Working Paper Series 25882). doi.org/10.3386/w25882

Long, H., Zaremba, A., Demir, E., Szczygielski, J. J., \& Vasenin, M. (2020). Seasonality in the crosssection of cryptocurrency returns. Finance Res. Lett., (35), 101566. doi.org/10.1016/j.frl.2020.101566

Markowitz, H. (1952). Portfolio Selection. J. Finance, (7), 77-91.

Mercik, A., \& Cupriak, D. (2019). Ryzyko systematyczne na rynku tokenów cyfrowych. Strategie interesariuszy na rynku finansowym (pp. 51-62). Warszawa: Wydawnictwo SGGW.

Nadarajah, S., \& Chu, J. (2017). On the inefficiency of Bitcoin. Econ. Lett., (150), 6-9. doi.org/10.1016/j. econlet.2016.10.033

Nichol, E., \& Dowling, M. M. (2014). Profitability and investment factors for UK asset pricing models. SSRN Electron. J. doi.org/10.2139/ssrn.2511166

Proposal for a Regulation of the European Parliament and of the Council on markets in crypto-assets, and amending Directive (EU) 2019/1937.

Razali, N., \& Wah, Y. B. (2011). Power comparisons of Shapiro-Wilk, Kolmogorov-Smirnov, Lilliefors and Anderson-Datling tests. J. Stat. Model. Anal., (2), 21-33.

Rivin, I., \& Scevola, C. (2018). The CCI30 Index. Retrieved from https://arxiv.org/abs/1804.06711

Schwartzkopff, D., Schwartzkopff, L., Botha, R., Finlayson, M., \& Cronje, F. (2017). CRYPTO20: The First Tokenized Cryptocurrency Index Fund.

Shapiro, S. S., \& Wilk, M. B. (1965). An analysis of variance test for normality (complete samples). Biometrika, (52), 591. doi.org/10.2307/2333709

Sharpe, W. F. (1964). Capital asset prices: A theory of market equilibrium under conditions of risk. J. Finance, (19), 425. doi.org/10.2307/2977928

Soto de, H. (2017). A tale of two civilizations in the era of Facebook and blockchain. Small Business Economics, 49(4), 729-739. doi.org/10.1007/s11187-017-9949-4

Tapscott, D., \& Tapscott, A. (2017). How blockchain will change organization.

Treynor, J. (1962). Toward a theory of market value of risky assets. In R. Korajczyk (Ed.), Asset pricing and portfolio performance: Models, Strategy and Performance Metrics (Unpublished manuscript Final version published in 1999, pp. 15-22). London: Risk Books.

Trimborn, S., \& Härdle, W. K. (2018). CRIX an index for cryptocurrencies. J. Empir. Finance, (49), 107-122. doi.org/10.1016/j.jempfin.2018.08.004

Underwood, S.(2016). Blockchain beyond bitcoin. Commun. ACM, (59), 15-17. doi.org/10.1145/2994581

Urbański, S. (2007). Time-cross-section factors of rates of return changes on the Warsaw Stock Exchange. Przeglad Stat., (54), 94-121.

Urquhart, A. (2016). The inefficiency of bitcoin. Econ. Lett., (148), 80-82. doi.org/10.1016/j.econlet.2016.09.019 
Waszczuk, A. (2013). A risk-based explanation of return patterns - evidence from the Polish stock market. Emerg. Mark. Rev., (15), 186-210. doi.org/10.1016/j.ememar.2012.12.002

Zaremba, A. (2014). Cross-sectional asset pricing models for the Polish market. SSRN Electron. J. doi. org/10.2139/ssrn.2396884

Zhang, W., \& Li, Y. (2020). Is idiosyncratic volatility priced in cryptocurrency markets? Res. Int. Bus. Finance, (54), 101252. doi.org/10.1016/j.ribaf.2020.101252

\section{ANALIZA RYZYKA RYNKOWEGO NA RYNKU KRYPTOAKTYWÓW. PORÓWNANIE INDEKSÓW CYFROWYCH AKTYWÓW}

Streszczenie: Na początku 2021 r. kapitalizacja rynku kryptoaktywów przekroczyła 1,5 bln USD, a na świecie funkcjonowało ponad 300 giełd, na których można było handlować ponad 8 tys. tokenów. W ramach badań związanych z dojrzałymi segmentami rynku finansowego (np. rynek akcji w Stanach Zjednoczonych) naukowcy i praktycy od kilkudziesięciu lat starają się zidentyfikować kluczowe czynniki ryzyka, dzięki którym możliwe jest wyjaśnienie premii za ryzyko kapitałowe inwestycji w daną klasę aktywów. W ostatnich latach wzrasta liczba badaczy próbujących zidentyfikować te czynniki dla kryptoaktywów. Celem niniejszego artykułu była analiza popularnych indeksów kryptoaktywów i zidentyfikowanie tych, które mogą być wykorzystane jako proxy portfela rynkowego do oszacowania wspomnianej premii za czynniki ryzyka. Wyniki badań wskazują, że czynnik ryzyka rynkowego jest istotnym elementem badanego rynku, a indeksami, które najlepiej go odzwierciedlają, są indeks składający się ze wszystkich kryptoaktywów ważonych kapitalizacją oraz Coin100, który zawiera tylko 100 największych kryptoaktywów.

Słowa kluczowe: kryptoaktywa, tokeny cyfrowe, łańcuch bloków, kryptowaluta, syatematyczne ryzyko, metoda wyceny aktywów kapitałowych. 